\title{
PENINGKATAN KOMPETENSI GURU DALAM PENYUSUNAN PENELITIAN TINDAKAN KELAS (PTK) MELALUI BIMBINGAN BERBASIS MGMP DI SMKN 7 MUARO JAMBI TAHUN PELAJARAN 2018/2019
}

\author{
LASA SIAGIAN \\ Kepala SMK Negeri 7 Muaro Jambi Provinsi Jambi \\ Email : sia-gian9@gmail.com
}

\begin{abstract}
ABSTRAK
Penelitian ini bertujuan untuk mengetahui efektifitas penerapan bimbingan kelompok berbasis kegiatan Musyawarah Guru Mata Pelajaran (MGMP) dalam meningkatkan kompetensi guru SMK Negeri 7 Muaro Jambi Provinsi Jambi dalam menyusun Penelitian Tindakan Kelas. Penelitian ini dipusatkan di SMK Negeri 7 Muaro Jambi sebagai tempat diselenggarakannya MGMP. Subyek penelitian yaitu dewan guru berjumlah 30 orang. Pelaksanaan Penelitian Tindakan Sekolah (PTS) ini dilakukan sebanyak 2 siklus. Masing-masing siklus terdapat empat tahapan yaitu perencanaan, pelaksanaan, observasi dan refleksi. Keberhasilan dalam penelitian ini adalah meningkatkanya kompetensi Guru SMK Negeri 7 Muaro Jambi adalah dengan indikator yaitu: jika $\geq 10 \%$ dari jumlah peserta bimbingan telah memperoleh nilai rata-rata $\geq$ 85,00. Hasil Penelitian Tindakan Sekolah (PTS) pada siklus II diperoleh data sebagai berikut ; 1) observasi pengawas $(4,22), 2)$ observasi guru $(4,14), 3)$ hasil kerja secara klasikal $(84,02)$. Indikator keberhasilan telah terlampaui Penelitian Tindakan Sekolah (PTS) dinyatakan berhasil, dan penelitian dihentikan pada siklus II. Bimbingan kelompok yang dilakukan terbukti efektif dalam upaya meningkatkan kompetensi guru SMK Negeri 7 Muaro Jambi dalam penyusunan proposal PTK karena $90 \%$ dari jumlah peserta sebanyak 30 orang guru telah berhasil menyusun proposal PTK sesuai harapan.
\end{abstract}

Kata Kunci: kompetensi guru, penelitian tindakan kelas, MGMP

\section{PENDAHULUAN}

Komponen yang dianggap paling penting dalam aktivitas pembelajaran adalah peran seorang guru. Guru wajib memiliki kualifikasi akademik, kompetensi, sertifikasi pendidik, sehat jasmani dan rohani, serta memiliki kemampuan untuk mewujudkan tujuan pendidikan nasional. Kompetensi secara umum berarti kewenangan untuk menentukan dan memutuskan sesuatu. Adapun dalam definisi yang lain dijelaskan bahwa kompetensi guru merupakan seperangkat penguasaan pengetahuanan kemampuan yang harus dimiliki guru agar dapat melaksanakan pekerjaannya secara benar dan bertanggung jawab (Baharun, 2018).

Berdasarkan Permendiknas No. 16 Tahun 2007, guru harus memiliki empat kompentensi, yaitu kompetensi pedagogik, kompetensi kepribadian, kompetensi sosial, dan kometensi profesional. Kompetensi profesional sangat erat dengan kemampuan guru dalam merencanakan, melaksanakan, dan mengevaluasi pembelajaran. Keberhasilan pelaksanaan pembelajaran dan evaluasi sangat ditentukan oleh baik-tidaknya perencanaan pembelajaran. Dengan demikian, guru yang profesional adalah guru yang memiliki keahlian sesuai dengan standar mutu pendidikan yang ditetapkan oleh pemerintah (Fardini, dkk, 2014).

Kualitas guru adalah salah satu komponen penting yang ikut berperan dalam usaha pembentukan sumber daya manusia yang potensial di bidang pendidikan. Karena, pendidikan adalah proses merubah manusia menjadi lebih baik, lebih mahir dan lebih terampil (Sudirman, 2020). Oleh karena itu, guru harus berperan secara aktif dan menempatkan kedudukannya sebagai tenaga kompeten, sesuai dengan tuntutan masyarakat yang semakin berkembang. Dalam penjelasan lain dikatakan bahwa kompetensi guru dapat diartikan sebagai kebulatan pengetahuan, keterampilan dan sikap yang diwujudkan dalam bentuk perangkat tindakan cerdas dan penuh tanggung jawab yang dimiliki seseorang guru untuk memangku jabatan guru sebagai profesi (Kusen, 2019). 
Begitu pula kompetensi guru dalam melaksanakan penelitian tindakan kelas merupakan bagian dari kompetensi profesional oleh sebab itu guru harus mampu melaksanakan penelitian tindakan kelas. Guru perlu melaksanakan penelitian tindakan kelas sebab dengan melaksanakan penelitian ini akan diperoleh manfaat ganda yaitu memperbaiki proses pembelajaran dan meningkatkan kemampuan guru dalam kegiatan pengembangan profesi. Guru pada dasarnya sudah melaksanakan penelitian tindakan kelas, meskipun rancangan, pelaksanaan dan evaluasinya belum sesuai dengan format penelitian tindakan kelas, demikian pula hasil temuan yang belum dilaporkan sesuai dengan pedoman yang sudah ditetapkan, namun guru belum menyadarinya jika ia telah melaksanakan penelitian tindakan kelas (Sukanti, 2008).

Dengan memilih masalah yang tepat guru sebagai peneliti selain dapat melakukan perbaikan, peningkatan dan perubahan proses pembelajaran yang lebih baik berdampak pula terhadap diri guru yaitu menumbuhkan sikap dan kemauan untuk selalu berupaya memperbaiki, meningkatkan dan melakukan perubahan atau timbulnya budaya dinamis dan menimbulkan budaya untuk meneliti atau menjadikan dirinya sebagai peneliti (Suhardjono, 2012). Pentingnya penelitian tindakan kelas dalam kegiatan pembelajaran, tujuan dan manfaat penelitian tindakan kelas, pelaksanaan penelitian tindakan kelas, kompetensi guru, dan upaya meningkatkan kompetensi guru melalui penelitian tindakan kelas. Dari uraian di atas tentang guru profesional, baik pendapat para pakar pendidikan maupun menurut pemerintah dapat dicirikan bahwa seorang guru profesional minimal harus memenuhi kompetensi koprofesiannya sebagai guru (Sa'bani, 2017).

Salah satu strategi dalam meningkatkan kompetensi guru untuk melaksanakan penelitian adalah dengan menerapkan kegiatan bimbingan kelompok. Bimbingan kelompok tepat dilakukan bagi guru dengan jumlah banyak dikarenakan adanya interaksi antar satu dengan yang lain. Dalam hubungan ini akan terjadilah suatu proses saling mempengaruhi. Dalam kaitannya dengan kelompok, antara anggota satu dengan anggota kelompok yang lain akan terjadi saling mempengaruhi (Bhakti, dkk, 2019). Proses saling mempengaruhi dalam kehidupan kelompok tersebut sejatinya menjadi landasan dapat dilakukannya bimbingan kelompok. Bimbingan kelompok memungkinkan beberapa individu dapat memanfaatkan dinamika kelompok semaksimal mungkin dalam memecahkan masalahnya. Penggunaan teknik dalam kegiatan bimbingan kelompok mempunya banyak fungsi selain dapat lebih memfokuskan kegiatan bimbingan kelompok terhadap tujuan yang ingin dicapai tetapi juga dapat membuat suasana yang terbangun dalam kegiatan bimbingan kelompok agar lebih bergairah dan tidak cepat membuat peserta jenuh mengikutinya (Romlah, 2006: 55).

Melalui pembahasan topik tentang mengemukakan pendapat, anggota kelompok dilatih untuk menguasai langkah-langkah dalam mengemukakan pendapat yang baik, sehingga diharapkan peserta mampu untuk mengemukakan pendapat tentang hal-hal yang dimengerti dan tidak dimengerti. Pada gilirannya, layanan bimbingan kelompok melalui dinamika kelompoknya mampu memberikan sumbangan yang besar kepada individu untuk meningkatkan pemahaman, mengembangkan potensi dan mampu membantu peserta mengambil keputusan yang tepat untuk kebaikan dirinya pada masa sekarang dan masa yang akan datang. Untuk menguji kebenaran dari apa yang telah diungkapkan, maka dibuktikan melalui penelitian (Amri, dkk, 2016).

Pendidikan dan pelatihan memiliki peranan penting dalam pengembangan keprofesionalan guru demi meningkatkan mutu pendidikan dan proses belajar mengajar di sekolah. Banyak solusi yang bisa dilakukan dalam upaya meningkatkan kompetensi guru SMK Negeri 7 Muaro Jambi dalam penyusunan proposal Penelitian Tindakan Kelas (PTK), diantaranya adalah melalui bimbingan kelompok. Pelaksanaan bimbingan kelompok ini bisa dilaksanakan melalui kegiatan Musyawarah Guru Mata Pelajaran (MGMP) khusus dalam penyusunan proposal PTK. Melalui kegiatan MGMP inilah diharapakan kepala sekolah selaku peneliti dapat melakukan bimbingan terhadap guru-guru SMK Negeri 7 Muaro Jambi dalam penyusunan proposal Penelitian Tindakan kelas (PTK) melalui tindakan nyata, terencana, terprogram dan terpantau secara langsung upaya-upaya meningkatkan kompetensi khususnya 
tata cara penyusunan proposal Penelitian Tindakan Kelas (PTK). Hal ini selaras dengan keinginan para guru untuk bersama-sama menyatukan langkah dan pemikiran menuju perbaikan mutu pendidikan dan kompetensi masing-masing guru dalam melaksanakan penelitian terutama PTK. Adapun keunggulan pelaksanaan bimbingan kelompok antara lain: 1) pembelajaran yang sulit bisa menjadi mudah, 2) bisa memecahkan permasalahan secara bersama- sama, 3) hasil kerja lebih berkualitas bila dibandingkan dengan pekerjaan sendirian, 4) menjalin tali silaturrahim dan kekeluargaan yang tinggi (Ridwan, 2016).

Kondisi nyata yang dihadapi oleh kebanyakan guru SMK Negeri 7 Muaro Jambi, masih banyak ditemukan bahwa guru belum memiliki kemampuan dan kemauan menyusun proposal Penelitian Tindakan Kelas (PTK). Faktor kemauan dan kemampuan yang minim tersebut berimbas pada kurangnya produktifitas guru dalam menghasilkan karya ilmiah terutama PTK. Alasan umum yang sering ditemukan berdasarkan wawancara dengan guru SMK Negeri 7 Muaro Jambi yang dapat dirangkum adalah;1) jumlah jam mengajar yang padat sehingga tidak ada waktu bagi guru untuk membuat proposal dan melaksanakan Penelitian Tindakan Kelas (PTK), 2) kesibukan dalam membuat perangkat pembelajaran yang berimbas pada tidak adanya kesempatan menyusun penelitian, 3) kesibukan guru mengoreksi hasil kerja siswa.

Persoalan di atas bisa diatasi manakala guru SMK Negeri 7 Muaro Jambi mampu untuk mengembangkan diri baik dilingkungan sekolah maupun melalui jaringan organisasi MGMP (Musyawarah Guru Mata Pelajaran). Musyawarah Guru Mata Pelajaran sama halnya dengan $\mathrm{KKG}$, merupakan suatu organisasi guru yang dibentuk untuk menjadi forum komunikasi yang bertujuan untuk memecahkan masalah yang dihadapi guru dalam pelaksanaan tugasnya seharihari di lapangan. MGMP berada di tingkat sekolah lanjutan, baik SMP, SMA maupun SMK (Irawan, 2018). Keberadaan MGMP di Kabupaten Muaro Jambi sebenarnya sudah mendapat pembinaan dari instansi terkait seperti Dinas Pendidikan. Namun keberadaannya masih belum difungsikan secara maksimal dalam membina anggota terutama kegiatan yang kaitannya dengan pengembangan kompetensi meneliti. Keberadaan MGMP masih dianggap sebagai kebutuhan program pemerintah, bukan sebagai wadah untuk mengembangkan profesionalime guru. Sejatinya melalui kegiatan MGMP, guru dapat bertukar informasi atau mengundang nara sumber untuk memecahkan permasalahan-permasalahan baik pada penguasaan materi ajar, perencanaan pembelajaran, pelaksanaan pembelajaran dan penilian hasil pembelajaran. Secara spesifik, MGMP diharapkan mampu meningkatkan kompetensi profesional guru dalam melaksanakan penelitian (Saragih dan Dewi, 2018). Program mengoptimalkan MGMP sebagai wadah kegiatan bimbingan kelompok bagi guru SMK Negeri 7 Muaro Jambi menjadi relevan untuk dilaksanakan dalam kaitannya dengan peningkatan kompetensi guru SMK Negeri 7 Muaro Jambi.

\section{METODE PENELITIAN}

Penelitian ini berbentuk Penelitian Tindakan Sekolah (PTS). Peneltian ini dilaksanakan di SMK Negeri 7 Muaro Jambi dengan Subyek penelitian berjumlah 30 (tiga puluh) guru yang terdiri atas laki-laki 12 orang dan perempuan 18 orang yang semuanya memerlukan bimbingan dalam penyusunan PTK. Adapun penelitian ini dilaksanakan selama 3 bulan yakni berlangsung dari Agustus sampai November 2018.

Analisis data penelitian dilakukan melalui analisis diskriptif kualitatif melalui pendataan analisis dan pembahasan terhadap data yang diperoleh dengan mencocokkan tingkat keoptimalan terhadap indikator keberhasilan/indikator kinerja.

Gambaran tahapan kegiatan tiap-tiap siklus dapat digambarkan sebagai berikut: 


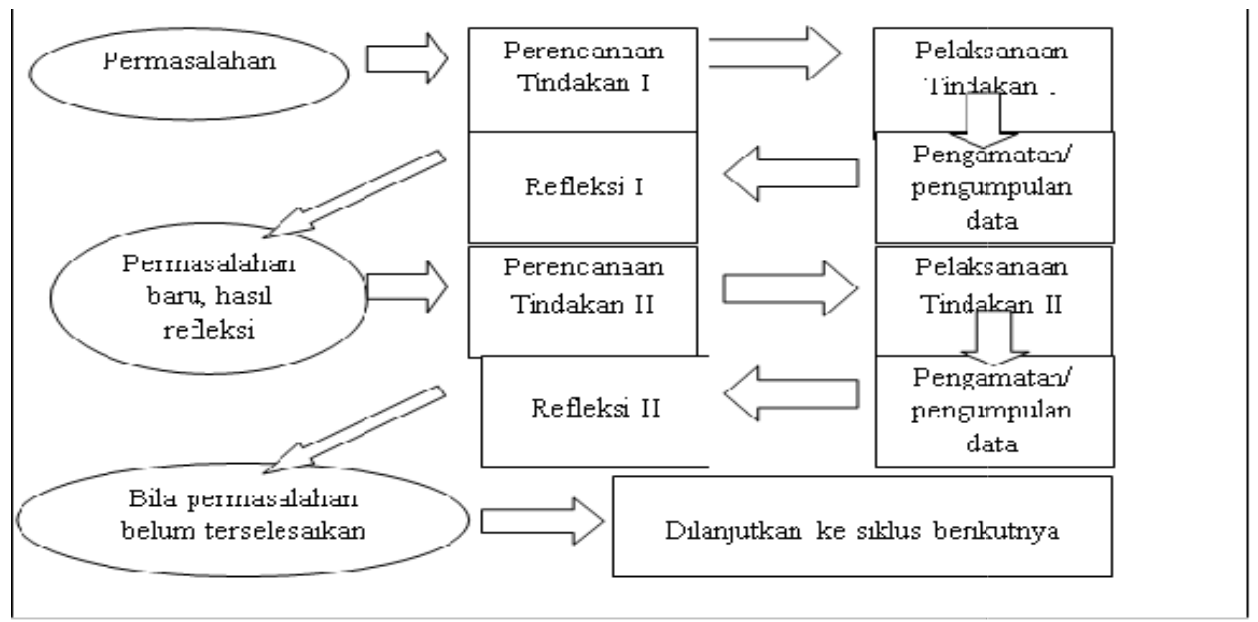

Gambar 1. Skenario Tindakan masing-masing Siklus I dan Siklus II

\section{HASIL DAN PEMBAHASAN \\ Siklus I}

Kepala sekolah selaku peneliti menyusun Rencana Pelaksanaan Pembimbingan (RPP) dengan memfokuskan pada skenario pelaksanaan pembimbingan yang kontekstual dan melibatkan aktifitas, kreatifitas, serta efektifitas seluruh guru SMK Negeri 7 Muaro Jambi sebagai peserta pembimbingan penyusunan proposal Penelitian Tindakan Kelas (PTK). Selanjutnya kepala sekolah selaku peneliti menyiapkan alat-alat seperti laptop, LCD, layar, dan semua bahan yang diperlukan oleh peserta selama pelaksanaan pembimbingan disiapkan dengan baik. Kegiatan penyusunan instrumen observasi kepala sekolah dan instrumen observasi guru difokuskan pada keterlaksanaan penyusunan proposal.

Selama proses penyampaian materi tentang penyusunan proposal Penelitian Tindakan Kelas (PTK), yang pelaksanaannya pada Bab I. Pendahuluan, kepala sekolah selaku peneliti memberikan contoh langsung tentang bagaimana membuat latar belakang masalah yang berujung munculnya judul penelitian, bagaimana membuat rumusan masalah dan pemecahannya, serta bagaimana membuat tujuan dan manfaat penelitian. Sedangkan untuk kajian pustaka dan metode penelitian cukup dijelaskan dan penyusunannya dijadikan tugas mandiri untuk dikerjakan diluar jam pembimbingan. Bagi guru yang memerlukan bimbingan dilaksanakan secara individual bisa pada jam kerja maupun diluar jam kerja. Pada akhir pembimbingan secara berkelompok, kepala sekolah memberikan tugas (PR) untuk dikerjakan di luar jam pembimbingan diharapkan waktu yang ditentukan semua peserta pembimbingan sudah selesai menyusun proposal PTK.

Data hasil observasi kepala sekolah yang dilakukan oleh observer yaitu pengawas pembimbing, diperoleh skor rata-rata sebesar 3,56, Observasi guru memperoleh skor rata- rata sebesar 3,62 dan hasil kerja secara individual penyusunan proposal Penelitian Tindakan Kelas (PTK) yang dikerjakan dalam proses pembimbingan selama siklus I yang dilanjutkan diluar pembimbingan sebagai tugas (PR) diperoleh nilai rata-rata sebesar 78,87.

Pada akhir pembimbingan kepala sekolah selaku peneliti merenung atas hasil perolehan data pada saat pengamatan dimana kepala sekolah selaku peneliti memperoleh skor rata-rata 3,56, sedangkan hasil pengamatan kegiatan selama bekerja sama dalam kelompok kecil diperoleh skor rata-rata 3,62 dan hasil akhir dari kerja individual secara klasikal baru tercapai dan nilai rata-rata klasikal 78,87.Perolehan skor dan nilai pada siklus I masih jauh di bawah rata-rata indikator kinerja yang diharapkan yaitu $\geq 4,00$ dan nilai rata-rata individual $\geq 85,00$, maka kepala sekolah selaku peneliti berupaya untuk memperbaiki dan menyempurnakan atas kesalahan-kesalahan dan kekurangan yang dilakukan oleh peneliti maupun guru selama proses pembimbingan pada siklus I. Maka dilanjutkan menuju tahap siklus II. 


\section{Siklus II}

Dalam penyusunan Rencana Pelaksanaan Pembimbingan (RPP) pada siklus II ini masih mengacu dan melanjutkan semua jenis kegiatan pembimbingan pada siklus I. Menyiapkan alat, sumber, bahan yang diperlukan selama pelaksanaan pembimbingan dari pagi sampai sore lebih ditekankan pada hal-hal yang krusial dan harus ada pada saat pembimbingan. Kegiatan penyusunan instrumen pengamatan/observasi baik pengamatan pada kegiatan pembimbingan oleh observer yang berasal dari pengawas selaku pembimbing maupun penyusunan instrumen pengamatan/observasi terbimbing oleh kepala sekolah selaku peneliti tentang jenis-jenis kegiatan guru peserta pembimbingan penyusunan proposal Penelitian Tindakan Kelas (PTK) masih mengacu pada instrumen pada siklus I. Pada prinsipnya sama tidak mengalami perubahan, yang disempurnakan hanya kesalahan tulis pada bagian subtansi masing-masing aspek yang diamati oleh observer. Penyusunan pedoman analisis hasil observasi kepala sekolah maupun hasil observasi guru masih mengacu pada instrumen yang sudah disusun pada siklus I.

Proses pembimbingan lanjutan penyusunan proposal Penelitian Tindakan Kelas

(PTK), dengan penekanan penyusunan Bab II tentang kajian pustaka dan Bab III tentang metode penelitian/prosedur penelitian. Kepala sekolah menjelaskan hal- hal yang penting yang terkait dengan kajian pustaka dan prosedur penelitian yang diselingi dengan tanya jawab dengan guru peserta pembimbingan dengan harapan kegiatan diskusi dan kerja kelompok nanti dapat berjalan lancar. Banyak pertanyaan- pertanyaan dari peserta yang mengarah pada kajian pustaka dan prosedur penelitian, dan kepala sekolah selaku peneliti mampu menjawabnya dengan baik.

Data hasil observasi kepala sekolah yang dilakukan oleh observer yaitu pengawas pembimbing, diperoleh skor rata-rata sebesar 4,22, Observasi guru memperoleh skor rata- rata sebesar 4,14 dan hasil kerja secara individual penyusunan proposal Penelitian Tindakan Kelas (PTK) yang dikerjakan dalam proses pembimbingan selama siklus I yang dilanjutkan diluar pembimbingan sebagai tugas (PR) diperoleh nilai rata-rata sebesar 84,02.

Renungan hasil tindakan pada siklus II oleh kepala sekolah selaku peneliti hasilnya adalah bahwa tindakan pembimbingan penyusunan proposal PTK pada siklus ini mengalami kemajuan yang sangat berarti, hal ini bisa terjadi karena kepala sekolah memperhatikan hal-hal yang menjadi kendala yang dirasakan pada siklus sebelumnya dengan demikian tindakan pada siklus ini lebih dioptimalkan. Observasi kepala sekolah memperoleh skor rata-rata $(4,22)$, sementara hasil observasi guru memeperoleh skor rata-rata $(4,14)$, dan perolehan nilai rata-rata hasil penyusunan proposal PTK adalah $(84,02)$, serta hasil pengamatan pada saat presentasi antar kelompok memperoleh skor rata-rata $(4,50)$.

\section{Pembahasan}

\section{Siklus I}

Peneliti menyusun Rencana Pelaksanaan Pembimbingan (RPP), menyiapkan alat, sumber, bahan dan lain-lain yang diperlukan dalam pelaksanaan pembimbingan, menyusun instrumen observasi kepala sekolah maupun observasi guru, dan menyusun pedoman analisis hasil observasi mengalami kendala, tetapi dapat diatasi dengan baik setelah meminta petunjuk kepada pengawas pembimbing.

Pada saat kepala sekolah selaku peneliti menyampaikan materi tentang tata cara penyusunan proposal Penelitian Tindakan Kelas (PTK) terdapat sedikit hambatan yaitu tingkat penyerapan peserta yang kurang seimbang. Faktor penyebabnya adalah karena ada guru yang sudah pernah membuat proposal PTK, dan ada guru yang belum sama sekali membuat proposal PTK. Solusinya adalah dengan dibentuknya kelompok besar, sehingga memudahkan dalam pembimbingan bagi guru yang masih kesulitan. Hasilnya semua peseta menjadi lebih dapat memahami dan bisa membuat draf proposal PTK walaupun masih belum sempurna.

Pada waktu pembimbingan dalam kelompok besar, terdapat kendala yaitu pada saat masih membimbing pada satu kelompok, kelompok lain juga sangat membutuhkan bimbingan. Hal ini terjadi karena masing-masing kelompok belum menunjuk teman sejawat yang dianggap mampu sebagai tutor sebaya. Setelah ditunjuk adanya tutor sebaya maka hambatan bisa 


\section{VOCATIONAL : Jurnal Inovasi Pendidikan Kejuruan Vol. 1 No. 3 Juli 2021 e-ISSN : 2774-6283 | p-ISSN : 2775-0019}

diminimalkan. Pelaksanaan pembimbingan dan kerja kelompok yang dilaksanakan dengan model ini membawa hasil yang menggembirakan karena semua peserta pembimbingan merasa diperhatikan dan semua bisa bekerja dengan tenang penuh dengan semangat kekeluargaan,demokratis, inovatif, kreatif dan menyenangkan.

Perolehan skor rata-rata pada sklus I ini adalah $(3,56)$ ini artinya indikator keberhasilan belum tercapai. Hasilnya proses pembimbingan berjalan lancar dan hasil skor rata-rata yang diperoleh oleh 35 (tiga puluh lima)orang guru selama mengikuti pembimbingan adalah $(3,62)$ ini artinya belum memenuhi indikator keberhasilan yang telah diisyaratkan. Dari 30 (tiga puluh lima) orang peserta yang dinyatakan telah berhasil baru dua orang yaitu Weny Anggraini, S.Pd dengan perolehan nilai rata-rata $(88,46)$, dan Suryana, ST dengan perolehan nilai rata-rata $(94,62)$. Meskipun kedua guru itu sudah dinyatakan telah berhasil, masih perlu perbaikan agar dalam siklus II nanti nilainya lebih meningkat.

Hasil observasi kepala sekolah, hasil observasi guru, dan perolehan nilai rata-rata penyusunan proposal Penelitian Tindakan Kelas (PTK) secara berturut-turut memperoleh hasil sebagai berikut: $(3,57),(3,62)$, dan $(78,87)$. Hasil ini masih belum memenuhi indikator keberhasilan dimana untuk observasi kepala sekolah maupun observasi diharapkan memperoleh skor rata- rata $\geq 4,0$ dan penyusunan proposal PTK diharapkan memperoleh nilai rata-rata $\geq 85,00$.

Dalam upaya melaksanakan jenis tindakan dalam upaya kegiatan tindak lanjut, kepala sekolah memberikan kesempatan untuk berkonsultasi diluar pembinaan secara klasikal yang dilaksanakan pada jam kerja dan atau diluar jam kerja sesuai kesepakatan antara kepala sekolahs selaku pembimbing dengan guru selaku terbimbing.

\section{Siklus II}

Pada tahapan perencanaan tindakan ini yang kegiatannya meliputi; 1) penyusunan Rencana Pembimbingan (RPP), 2) penyediaan alat, sumber bahan, 3) penyusunan lembar observasi, 4) menyusun pedoman analisa hasil observasi, dan 5) pembuatan jadwal kegiatan pembimbingan, pada prinsipnya sama dengan apa yang dilakukan pada siklus I. Penekanan pada kegiatan ini adalah perbaikan dan penyempurnaan kekurangan dan kesalahan yang pernah dilakukan pada siklus I. Secara umum hambatan tidak ada, begitupun faktor penyebabnya juga tidak ada, sehingga adalam penyusunan perencanaan tindakan pada siklus II berjalan sesuai dengan apa yang telah direncanakan.

Dalam pelaksanaan pembimbingan penyusunan proposal Penelitian Tindakan Kelas (PTK) mengalami sedikit hambatan yaitu tingkat kedisiplinan peserta khususnya ketepatan kehadiran masih belum sesuai dengan yang direncanakan. Faktor penyebabnya adalah ada beberapa guru yang kebetulan disekolah ada jam mengajar, sebagian besar guru yang demikian memberikan tugas terlebih dahulu baru menghadiri pembimbingan penyusunan proposal Penelitian Tindakan Kelas ( PTK). Solusi yang dilakukan oleh kepala sekolah selaku peneliti dengan mengundur waktu pelaksanaan tanpa mengurangi arti pentingnya pembimbingan. Hasilnya semua guru yang berjumlah 30 orang dapat hadir mengikuti pembimbingan.

Pada kegiatan ini kepala sekolah memperoleh skor rata-rata $(4,22)$, sementara perolehan skor rata-rata hasil pengamatan kegiatan guru dalam kelompok adalah $(4,14)$ ini artinya kedua kegiatan itu sudah melampui indikator keberhasilan yang telah ditetapkan yaitu $\geq 4,0$. Sementara hasil nilai rata-rata dari penyusunan proposal adalah $(84,02)$, ini artinya ini artinya indikator keberhasilan $(85,00)$ belum tercapai. Sedangkan keberhasilan secara individual sejumlah 7 orang dari 30 orang yang mengikuti pembimbingan dalam penyusunan proposal PTK sudah berhasil dengan memperoleh presentase 17,14\%, ini artinya indikator keberhasilan yang menyatakan $\geq 10 \%$ peserta memperoleh nilai rata-rata $\geq 85,00$. Kenyataannya yangsudah memperoleh nilai rata-rata $\geq 85,00$ ada7 orang. Artinya indikator keberhasilan telah tercapai. Pada akhir pembimbingan diadakan presentasi tiap kelompok yang diwakili oleh salah satu anggota kelompok secara acak, hasilnya adalah kelompok guru yang mengajar di kelas X memperoleh skor rata-rata $(4,25)$, kelompok guru yang mengajar di kelas XI memperoleh skor 


\section{VOCATIONAL : Jurnal Inovasi Pendidikan Kejuruan Vol. 1 No. 3 Juli 2021 e-ISSN : 2774-6283 | p-ISSN : 2775-0019}

rata-rata $(4,50)$, sedangkan kelompok guru yang mengajar di kelas XII memperoleh skor ratarata $(4,75)$.

Setelah selesaai siklus II kepala sekolah selaku peneliti diberikan beberapa saran dari observer antara lain: 1) proses bimbingan sudah baik tetapi masih perlu ditingkatkan, 2) sebagian besar guru peserta bimbingan sudah merasa senang dan bisa menerima materi serta dapat mempraktekkan secara langsung, tetapi masih ada 3 (tiga) orang peserta yang masih kelihatan kurang mengerti. Selanjutnya peneliti menganalisis data perolehan pada siklus II. Hasil observasi kepala sekolah memperoleh skor rata-rata $(4,22)$, hasil observasi guru memperoleh skor rata-rata $(4,14)$, sementara nilai rata-rata hasil penyusunan proposal PTK $(84,02)$ dan yang terakhir skor rata-rat hasil presentasi kelompok $(4,50)$ kategori baik.

Dari perolehan skor dan nilai rata-ratapada siklus II dinyatakan telah berhasil karena indikator keberhasilan telah dicapai.Karena indikator keberhasilan sudah tercapai maka Penelitian Tindakan Sekolah (PTS) dinyatakan telah "Berhasil", maka Penelitian Tindakan Sekolah (PTS) dihentikan pada "Siklus II".

\section{KESIMPULAN}

Berdasarkan hasil penelitian tindakan sekolah (PTS) yang dilakukan, maka dalam disimpulkan bahwa Bimbingan kelompok berbasis MGMP sangat efektif dalam upaya meningkatkan kompetensi guru SMK Negeri 7 Muaro Jambi dalam penyusunan Penelitian Tindakan Kelas (PTK). Hal ini dapat dibuktikan bahwa dalam proses pembimbingan penyusunan Penelitian Tindakan Kelas (PTK). Hal tersebut dibuktikan dengan jumlah peserta bimbingan telah memperoleh nilai rata-rata $\geq 85,00$. Hasil Penelitian Tindakan Sekolah (PTS) pada siklus II diperoleh data sebagai berikut ; 1) observasi pengawas $(4,22), 2)$ observasi guru $(4,14), 3)$ hasil kerja secara klasikal $(84,02)$. Indikator keberhasilan telah terlampaui Penelitian Tindakan Sekolah (PTS) dinyatakan berhasil, dan penelitian dihentikan pada siklus II.

\section{DAFTAR PUSTAKA}

Amri, K., Syahniar, S., \& Nirwana, H. (2016). Peningkatan Kemampuan Mengemukakan Pendapat Melalui Layanan Bimbingan Kelompok. Konselor, 3(2), 75-81.

Baharun, H. (2018). Peningkatan kompetensi guru melalui sistem kepemimpinan kepala madrasah. At-Tajdid: Jurnal Ilmu Tarbiyah, 6(1), 1-26.

Bhakti, C. P., Hartini, S., \& Fauziah, M. (2019). Pelatihan peningkatan kompetensi melakukan bimbingan kelompok bagi guru bimbingan dan konseling SMP di Kabupaten Sleman. Jurnal Pemberdayaan: Publikasi Hasil Pengabdian Kepada Masyarakat, 3(2), 231-236.

Fahdini, R., Mulyadi, E., Suhandani, D., \& Julia, J. (2014). Identifikasi Kompetensi Guru sebagai Cerminan Profesionalisme Tenaga Pendidik di Kabupaten Sumedang. Mimbar Sekolah Dasar, 1(1), 33-42.

Irawan, A. (2018). Meningkatkan Kompetensi Guru SMP Negeri 2 Wera Dalam Penyusunan Proposal Penelitian Tindakan Kelas (PTK) Melalui Bimbingan Kelompok Berbasis MGMP Tahun Pelajaran 2017/2018 di SMP Negeri 2 Wera. JISIP (Jurnal Ilmu Sosial dan Pendidikan), 2(2).

Kusen, K., Hidayat, R., Fathurrochman, I., \& Hamengkubuwono, H. (2019). Strategi Kepala Sekolah Dan Implementasinya Dalam Peningkatan Kompetensi Guru. Idaarah: Jurnal Manajemen Pendidikan, 3(2), 175-193.

Romlah, T. (2006). Teori dan Praktek Bimbingan Kelompok. Malang: UMM Press.

Ridwan, R. (2016). Meningkatkan Kompetensi Guru dalam Penyusunan Proposal Penelitian Tindakan Kelas (PTK) Melalui Bimbingan Kelompok Berbasis MGMP. Jurnal Kependidikan: Jurnal Hasil Penelitian dan Kajian Kepustakaan di Bidang Pendidikan, Pengajaran dan Pembelajaran, 2(1). 
Sa'bani, F. (2017). Peningkatan kompetensi guru dalam menyusun RPP melalui kegiatan pelatihan pada MTs Muhammadiyah Wonosari. Jurnal Pendidikan Madrasah, 2(1), 1322.

Saragih, M., \& Dewi, R. S. (2018). Efektifitas Musyawarah Guru Mata Pelajaran Untuk Meningkatkan Kompetensi Guru Bahasa Inggris Di Kota Binjai. Kumpulan Penelitian dan Pengabdian Dosen, 1(1).

Sudirman, S. (2020). Upaya Peningkatan Kompetensi Guru Dalam Menyusun Silabus Dan Rpp Melalui Supervisi Akademik Yang Berkelanjutan Di Sman 1 Simboro Kabupaten Mamuju. Celebes Education Review, 2(2), 81-90.

Suhardjono, dkk, (2012). Publikasi Ilmiah Dalam Kegiatan Pengembangan Keprofesian Berkelanjutan Bagi Guru. Jakarta: Cakrawala Indonesia

Sukanti, S. (2008). Meningkatkan kompetensi guru melalui pelaksanaan penelitian tindakan kelas. Jurnal Pendidikan Akuntansi Indonesia, 6(1). 